\title{
Intersekcjonalny wymiar polskiego dyskursu prasowego niepełnosprawności i starości
}

Medialny dyskurs niepełnosprawności i starości skłania do refleksji zarówno nad samym dyskursem ważnych społecznie zjawisk i tematów, jak i przyczynami oraz konsekwencjami ich wspólnego występowania w materiałach publicystycznych. Coraz częściej pojawiają się teksty, które łączą tematykę starości z pytaniami o poziom funkcjonowania człowieka w podeszłym wieku. Jakość życia w starości to z jednej strony kwestia biologiczna (stanu psychofizycznego), z drugiej to kwestia społeczna (osamotnienia, wsparcia, opieki, środków do życia). Tematyka starości bywa tożsama z tą poświęconą niepełnosprawności, zwłaszcza, gdy dotyczy analiz związanych z wykorzystaniem nowoczesnych technologii w poprawianiu jakości funkcjonowania osób z niepełno- sprawnością i/lub w późnej starości. W niniejszym artykule przedstawiona została feministyczna teoria przecięć (intersekcjonalność) jako kluczowa perspektywa badawcza w obrębie interdyscyplinarnych studiów nad niepełnosprawnością (disability studies) a zarazem ważna rama teoretyczna medialnego dyskursu niepełnosprawności i starości. Na bazie wskazanych obszarów przecięć niepełnosprawności i starości przeprowadzona została przykładowa analiza ich dyskursu w wybranych tekstach prasowych.

Słowa kluczowe: niepełnosprawność, starość, intersekcjonalność, dyskurs prasowy, analiza dyskursu, ablizm, ageizm

\section{The intersectional dimension of Polish press discourse of the disability and old age}

Media discourse of disability and old age obliged not only to reflection on the discourse of socialy important phonomenons and topics, but also on the reasons and conseqences of their mutual apperance in journalistic materials. There are more and more texts in which the old age topic appears together with the questions about the functioning level of the elderly people. The quality of life in an old age is - on the one hand - the biological matter (of the psychophysical state), but - on the other hand - the social matter (of the solitude, support, care, livelihood). The themes of the old age and disability are sometimes identical, particulary when they concern the usament of modern technologies in the improwment of the quality of life of people with disabilities or/and in the late old age. The intersectional feminism was presented in the article as the key research perspective in the area of the interdisciplinary disability studies and, at the same time, as the important theoretical frame of the disability and old age media discourse. The example of the disability and old age discourse in the selected press texts was based on the areas of the disability and old age intersection indicated in the article.

Keywords: disability, old age, intersectionality, press discourse, discourse analysis, ablism, ageism 


\section{Wprowadzenie}

Z nadziejami i obawami związanymi ze spodziewanym wydłużaniem się przeciętnego okresu ludzkiego życia kojarzone jest pytanie o jakość funkcjonowania człowieka dożywającego 120., a może i 150. lat. „Czy możemy żyć 150 lat zdrowi i sprawni?" (Polityka. Niezbednik Inteligenta, 2017) to okładkowe pytanie jednego z numerów „Niezbędnika Inteligenta”, cyklicznego dodatku „Polityki”, poświęconego w całości tematyce transhumanistycznej. Rozważania na temat przyszłości człowieka coraz częściej skupiają się wokół wykorzystania osiągnięć technologicznych nie tylko w kontekście leczniczym i rehabilitacyjnym, ale także w odniesieniu do możliwości regenerowania i/lub zastępowania zużywających się (starzejących się) organów ludzkiego ciała. Tak sformułowane kwestie w oczywisty sposób pobudzają również do studiów (bio)etycznych, które równolegle z postępem technologicznym analizują fenomen postczłowieka. Najbardziej symptomatyczne jest jednak połączenie pytania o „zdrowie i sprawność” z dywagacjami na temat długości ludzkiego życia.

Problematyka transhumanistyczna stanowi inspirujący obszar badań i analiz teoretycznych, łącząc zagadnienia, które w nowy sposób ujmują aktualne i przyszłe wymiary niepełnosprawności i starości jako fenomenów biologicznych oraz społecznych. Z drugiej strony jest to jedynie fragment, choć bardzo znaczący, prasowego dyskursu niepełnosprawności i choroby, rozwijanego w tekstach o zróżnicowanych walorach merytorycznych i poznawczych. Analiza tego dyskursu może uwzględniać wiele tropów teoretycznych, wśród których chciałbym zwrócić uwagę na teorię przecięć, nazywaną również analizą intersekcjonalną (zob. Johnson 2009). Feministyczne korzenie tej teorii mogą w kontekście niniejszych rozważań posiadać dodatkowy walor uświadamiający mechanizmy pomijania pewnych wątków w rozważaniach na temat źródeł dyskryminacji określonych grup osób o złożonej strukturze wewnętrznej. Zupełnie bowiem inaczej kształtuje się obecna i przewidywana sytuacja osobista i społeczna osób z niepełnosprawnością i starych, jeśli uwzględnione zostanie znaczenie - przykładowo - czynników ekonomicznych i neoliberalny wymiar edukacji, opieki, leczenia czy rehabilitacji.

Niepełnosprawność i starość bywają traktowane jako stany niemalże tożsame, prezentowane przez pryzmat niskiej jakości życia i ograniczeń funkcjonalnych. W obu przypadkach aktualna sytuacja człowieka jest najczęściej ujmowana z uwzględnieniem czynników biologicznych (zdrowie, sprawność), społecznych (izolacja, marginalizacja, wykluczenie) i ekonomicznych (niskie dochody, brak zajęcia, korzystanie ze wsparcia). Przypadki dobrego (szczęśliwego, spełnionego, zasobnego, pożytecznego, aktywnego...) życia w starości i/lub z niepełnosprawnością stanowią rodzaj sensacji (medialnej) związanej z dominacją obrazu prze- 
ciwnego, w czym ujawnia się kluczowa rola przekazów medialnych i kreowanych tą drogą dyskursów niepełnosprawności i starości.

\section{Wokół znaczeń i przecięć niepełnosprawności i starości}

Feministyczna teoria przecięć ilustruje powtarzający się proces dostrzegania powierzchowności i nieadekwatności jednowymiarowego ujmowania zjawisk dotyczących funkcjonowania człowieka. Konstatacja, iż ogólnie ujęta walka o prawa kobiet może nie uwzględniać innych niż płeć czynników dyskryminacji, okazała się przełomem nie tylko na gruncie studiów feministycznych, ale także $\mathrm{w}$ analizach poświęconych, między innymi, niepełnosprawności i starości. $W$ istocie, klasyczna już teoria Kimberlé Crenshaw (1989) powstała w ramach krytycznych studiów rasowych (critical race studies), ujawniając inny, zwielokrotniony wymiar opresji doświadczanej przez czarne kobiety, również ze strony dominujących $\mathrm{w}$ dyskursie feministycznym białych aktywistek. Obecnie intersekcjonalność, jak podaje Patricia Collins (2015), jest krytycznym poglądem, zgodnie z którym „rasa, klasa, płeć, seksualność, etniczność, narodowość, sprawność i wiek" nie są odrębnymi, niepowiązanymi kategoriami, lecz stanowią zestaw zjawisk wzajemnie konstruujących ich istotę. Wymieniona autorka traktuje ponadto intersekcjonalność jako projekt wiedzy, której naukowy byt uzasadniają niezmiennie trwałe zjawiska stosunków władzy i nierówności społecznych. Z tej racji Collins (2015: 1) zaproponowała dookreślenie intersekcjonalności jako relacji trzech obszarów: 1) badań umiejscowionych w stosunkach władzy; 2) analitycznych strategii, zapewniających nowe ujęcie zjawisk społecznych, oraz 3) krytycznej działalności promującej projekty sprawiedliwości społecznej.

Krytyczne podejście do problematyki niepełnosprawności doprowadziło do przezwyciężenia poglądu o "naczelnym statusie" i „,domniemanej jednorodności wyobcowania odczuwanego przez osoby niepełnosprawne" (Barnes, Mercer 2008, 2: 72), co wprowadziło kontekst intersekcjonalny do interdyscyplinarnych badań nad niepełnosprawnością (disability studies). Rosnąca świadomość podziałów społecznych jako źródła dyskryminacji przyczyniła się do ugruntowania intersekcjonalnej zasady zwielokrotnionej i jednoczesnej opresji, której wyrazem są skumulowane doświadczenia osób łączących w swej biologicznej i społecznej charakterystyce cechy najczęściej uruchamiające zachowania dyskryminacyjne. Powołując się na liczne opracowania teoretyczne i badawcze, C. Barnes i G. Mercer (2008: 72) stwierdzają, że:

domniemana jednorodność wyobcowania odczuwanego przez osoby niepełnosprawne została podważona przez postulat, by badania nad niepełnosprawnością uwzględ- 
niły inne czynniki, takie jak płeć, rasa i etniczność, orientacja seksualna, wiek i klasa społeczna.

Należy, oczywiście, zaznaczyć, że wymieniona w cytowanym wyliczeniu kategoria wieku obejmuje całość ludzkiego życia, a więc starość stanowi tylko jeden z wymiarów uszczegóławiających zagadnienia poświęcone wspólnym doświadczeniom ze względu na wiek i niepełnosprawność. Co istotne, sytuacja człowieka z niepełnosprawnością przez długi czas była wiązana głównie z problematyką edukacyjną bądź pracy zawodowej, co w równej mierze doprowadziło do zmarginalizowania intersekcjonalnych ujęć zarówno starości i niepełnosprawności, jak dzieciństwa i niepełnosprawności (zob. Curran, Runswick-Cole 2013). Z drugiej strony, próby połączenia różnych fenomenów bywają pozorne lub nieudane. Przykładowo, w książce pod redakcją A. Leszczyńskiej-Rejchert i E. Kantowicz (2012) jedynie tytuł - Stereotypy a starość i niepełnosprawność - zawiera intersekcjonalną intencję, natomiast treść opracowania została skrupulatnie rozdzielona na dwie części - osobno poświęcone starości i niepełnosprawności.

Relacja niepełnosprawności i starości w szczególny sposób wzmacnia kategorie opresyjne opisywane $\mathrm{w}$ interdyscyplinarnym dyskursie naukowym pojęciami (dis)ablizm i ageizm, które wciąż dość słabo są obecne w języku polskim w zestawieniu z o wiele bardziej ugruntowanymi i zrozumiałymi terminami, jak rasizm czy seksizm, stanowiącymi zresztą historyczno-semantyczny wzór pojęć nazywających i wyjaśniających postawy dyskryminacyjne. Kontekstualne rozumienie niepełnosprawności jako fenomenu nie tylko biologicznego (medycznego), ale także społecznego, odzwierciedla ścieranie się dwóch ugruntowanych modeli teoretycznych (medycznego i społecznego), czego efektem jest ostateczne uznanie, iż czynniki powodujące niepełnosprawność nie obejmują jedynie "struktur i funkcji ciała", ale także elementy środowiskowe, w tym zwłaszcza odnoszące się do społecznych oczekiwań wobec form ludzkiej aktywności i uczestnictwa w życiu społecznym (zob. Międzynarodowa Klasyfikacja Funkcjonowania, Niepełnosprawności i Zdrowia, 2001).

W przypadku starości pojawiają się analogiczne, biologiczno-społeczne przesłanki definicyjne, odnoszące się z jednej strony do obserwowalnych skutków procesu starzenia się, z drugiej natomiast do stopniowego wycofywania się z aktywności zawodowej. Ze starością wiązane jest pojęcie słabości (ang. frailty), rozumiane w odniesieniu do osób w podeszłym wieku (elderly people) jako:

stan całkowitego zaburzenia rezerw fizjologicznych, obejmujących wiele narządów i systemów. Kliniczny wymiar słabości manifestuje się zwiększoną podatnością na wewnętrzne i środowiskowe stresory przy jednoczesnym zmniejszeniu możliwości ich przezwyciężania oraz utrzymania fizjologicznej i psychospołecznej homeostazy. Słabość geriatryczna dotyczy 20-30\% populacji osób w wieku powyżej 75 lat i wzrasta wraz z postępującym wiekiem. Zaobserwowano związek słabości z długotrwałymi, 
niekorzystnymi skutkami - zwiększonym ryzykiem zespołów geriatrycznych, zależnością, niepełnosprawnością, hospitalizacją, umiejscowieniem w instytucji i śmiertelnością (Topinkova 2008: 6).

Starość może być zatem rozumiana jako postępująca i nieodwracalna utrata zasobów, odnosząca się w równej mierze do biologicznego i społecznego wymiaru ludzkiego funkcjonowania. Negatywne definiowanie starości zdeterminowane jest głównie jej przeciwstawianiem młodości, co niesie podobne konsekwencje, jak semantyczne i pragmatyczne zestawienie fenomenu sprawności z niepełnosprawnością. Można więc o relacjach dyskryminacyjnych myśleć w kontekście następujących układów pojęć: ablizm - dysablizm oraz adultyzm - ageizm. Zapisane w tych zestawieniach fenomeny sprawności i młodości są nie tylko stanami społecznie pożądanymi z przyczyn utylitarno-kulturowych, ale określają zarazem standardy biologiczno-społeczne, będące podstawą marginalizacji i wykluczenia (czasami zwielokrotnionych intersekcjonalnie) osób, które nie spełniają norm zdrowotnych, psychologicznych, edukacyjnych bądź społeczno-kulturowych. Z tego względu ablizm nie może być zrównany z dysablizmem, oznaczającym jednoznacznie dyskryminację ze względu na niepełnosprawność, lecz wymaga uwzględnienia teoretycznych i praktycznych kontekstów współczesnej polityki i ekonomii.

Zgodnie zatem z tym kierunkiem rozważań można przyjąć za Danem Goodleyem (2014), że ablizm dotyczy nie tylko osób z niepełnosprawnością, lecz stanowi swoisty zbiór zasad funkcjonowania współczesnych, rozwiniętych społeczeństw, faworyzujący te osoby, których warunki psychofizyczne w pełni odpowiadają neoliberalnym standardom ekonomicznym i normom społeczno-kulturowym. Należy w tym miejscu odnotować, że w polskich opracowaniach, także tych poświęconych bezpośrednio problematyce antydyskryminacyjnej (zob. Cieślikowska 2010), brakuje jasnego rozróżnienia terminologii odnoszącej się do postaw dyskryminacyjnych, których przyczyną jest sprawność człowieka. Tymczasem wprowadzenie wzmiankowanego rozróżnienia na gruncie interdyscyplinarnych studiów nad niepełnosprawnością (interdisciplinary disability studies) było wyrazem przezwyciężenia niedostatków modelu społecznego, z podkreśleniem dynamicznej natury negatywnych postaw społecznych, co wymaga uwzględnienia zmiennych kontekstów analizowania norm ludzkiego funkcjonowania.

Zadawane pod wpływem opresyjnych zachowań intersekcjonalne pytania o istotę i zależności tożsamości płciowej, rasowej czy klasowej, objęły także kwestie dopełniające ludzką wielowymiarowość, w tym sprawność i wiek. Feminizm skorzystał z kategorii esencjalizmu i konstruktywizmu, by zdefiniować i opisać różnice między biologicznym (naturalnym) ujmowaniem płci a jej kulturowym wymiarem (zob. Hyży 2010). Nurty feminizmu promujące konstruktywizm płciowy podważają naturalny (esencjalny) wymiar istnienia człowieka, a więc także 
naturę kobiety i mężczyzny, co warto przeanalizować w kontekście rywalizacji ujęć esencjalnych i konstruktywistycznych na gruncie studiów nad niepełnosprawnością. Rozważania na temat biologicznej istoty i kulturowego konstruowania niepełnosprawności można umiejscowić w paralelnej perspektywie wyjaśniającej radykalizm feministycznego konstruktywizmu:

Krytyczne analizy esencjalizmu w różnych jego postaciach doprowadziły wiele feministek do przypuszczenia, że kategoria „,człowiek” czy „kobieta”, zwłaszcza w zastosowaniu normatywnym, nie są pojęciami uniwersalnymi, ponadhistorycznymi, lecz zostały społecznie skonstruowane, zawsze w uzależnieniu od interesów i poglądów ich aktualnych użytkowników (Hyży 2010: 51).

Ważne jest dostrzeżenie i podkreślenie, że za społeczną konstrukcją wybranego zjawiska kryje się działanie obejmujące jego nazwanie i zróżnicowane zdominowanie. Stąd w przypadku badań związanych z niepełnosprawnością najbardziej eksploatowanymi są teorie feministyczne, postkolonialne i poststrukturalne (zob. Goodley, Hughes, Davis 2012). Susan Wendell (1996: 58), dotknięta stwardnieniem zanikowym bocznym, jedna z wielu osób łączących działalność na rzecz osób z niepełnosprawnością z pracą naukową, w tekście o jednoznacznie intersekcjonalnym charakterze zawarła następujące, własne wyjaśnienie podejścia konstruktywistycznego:

Rozumiem niepełnosprawność jako społecznie konstruowaną w ramach przejścia od społecznych warunków, które bezpośrednio powodują choroby, urazy czy słabą kondycję fizyczną, do subtelnych czynników kulturowych, które określają standardy normalności i wykluczają z pełnego życia społecznego, tych ludzi, którzy tych standardów nie osiągają.

Bezpośrednią konsekwencją współwystępowania opcji esencjalnych i konstruktywistycznych jest kluczowe rozróżnienie sensu wyrażeń: „osoba niepełnosprawna" i "osoba z niepełnosprawnością", ukształtowanych językowo osobno na gruncie brytyjskich (disabled person) i amerykańskich (person with disability) studiów nad niepełnosprawnością (disability studies) (zob. Goodley 2011). Warto zastanowić się, dlaczego w podobnym sposób mówi się i pisze o chorobie - „człowiek chory” $\mathrm{i}$ „"człowiek z chorobą (przykładowo - przewlekłą, zakaźną, rzadką lub nowotworową, wieńcową czy dwubiegunową), ale w żaden sposób nie można byłoby zrozumieć sensu współwystępowania wyrażeń: „człowiek stary” i „człowiek ze starością". Wydaje się, że język dość często okazuje się systemem i narzędziem zbyt sformalizowanym, by wyrazić zróżnicowane stany funkcjonowania człowieka, uwzględniające zarówno jego wymiar naturalny (biologiczno-esencjalny), jak i społecznie konstruowany.

Językowe ulokowanie przedstawionych analiz i stanowisk teoretycznych, stanowiących zarówno podstawę zróżnicowanych studiów interdyscyplinarnych, 
jak i efekt prac badawczych, uzasadnia potrzebę wnikliwego i krytycznego analizowania dyskursu jako sfery kształtowania się i ugruntowywania relacji władzy i podporządkowania.

\section{Przecięcia w prasowym dyskursie niepełnosprawności i starości - założenia badawcze i analiza}

Zaprezentowana $\mathrm{w}$ dalszej części niniejszego artykułu analiza dyskursu medialnego niepełnosprawności i starości jest jedynie fragmentaryczną ilustracją do podjętych wcześniej rozważań teoretycznych. Przedstawione zagadnienia zasługują na pewno na dużo obszerniejszy, wręcz monograficzny tekst, który mógłby się zmierzyć nie tylko z formalnym wymiarem analizy dyskursu, ale wskazałby również, w oparciu o odpowiednio bogaty materiał badawczy i spójne konteksty teoretyczne, obszary niezbędne w przypadku krytycznej analizy dyskursu (KAD), a więc językowo wyrażone i utrwalone nierówności społeczne, przy jednoczesnym wspieraniu działania "na rzecz emancypacji dyskryminowanych grup, które są wykluczane z udziału w dyskursie lub marginalizowane" (Grzymała-Kazłowska 2004: 25). Intencją tego tekstu jest jedynie wskazanie przykładów medialnej obecności przypadków zwielokrotnionej opresji, z uwzględnieniem socjolingwistycznej specyfiki KAD, czyniącej przedmiotem zainteresowania nie tyle sam język jako tworzywo dyskursu, ile procesy społeczne z ich dyskursywną naturą. Chodzi mianowicie o wskazanie tych relacji, które opierają się na dominacji i zniewoleniu, w czym ujawniają się nierówne stosunki władzy, a w konsekwencji ciąg procesu dyskryminacyjnego od lekceważenia, przez marginalizację po wykluczenie, czemu najczęściej towarzyszy przemoc jawna i/lub symboliczna (zob. Duszak, Fairclough 2018: 15 i n.).

Badawcze pytanie o dyskursywne przecięcia niepełnosprawności i starości $\mathrm{w}$ przekazach medialnych $\mathrm{w}$ naturalny sposób jest powiązane $\mathrm{z}$ teoretycznym zapleczem badań nad mechanizmami kreowania i funkcjonowania sfery publicznej. Rola mediów jest w tym przypadku pierwszorzędna, gdyż swobodny dostęp do informacji i środków masowego przekazu jest warunkiem niezbędnym do zaistnienia sfery publicznej (zob. Dobek-Ostrowska, Wiszniowski 2001: 35), którą - za Jürgenem Habermasem (za: Giddens 2007: 486) - można przyrównać do „sceny, na której toczy się publiczna debata nad kwestiami ważnymi dla ogółu i formułowane są opinie na ich temat".

Obserwujemy właśnie, jak starość stała się - z różnych przyczyn - jedną z najważniejszych "kwestii ważnych dla ogółu”, wywołując medialny dyskurs zjawiska, prezentowanego przede wszystkim w kontekście powszechności. W dużej li- 
czbie tekstów prasowych poświęconych starości (dzienników i tygodników opinii) punktem wyjścia są informacje statystyczno-demograficzne, których funkcją medialną jest skrótowe ukazania skali i aspektów rozwojowych zjawiska. Informacja ilościowa może jednak zostać przekazana w różnej formie językowej.

W 1990 roku przeciętna długość życia wynosiła 66 lat dla mężczyzn i 75 dla kobiet. Według danych GUS w 2015 roku mężczyźni żyli średnio 74 lata, kobiety 81,5. Przez ćwierć wieku nasze statystyczne życie wydłużyło się o 6-8 lat. Coraz częściej w jednej rodzinie żyją cztery, a nie trzy pokolenia. A przy obecnej długości życia dzieci mogłyby spotkać nawet swoich prapradziadków (Manthey 2017).

Jest w Polsce milion mieszkań, w których krząta się wokól siebie samotny stary człowiek. Czasem o jego nieistnieniu zawiadamiają muchy (Gietka 2017b).

Pierwszy cytat, z artykułu z "Gazety Wyborczej”, zamieszczonego w dziale „Nauka”, wprowadza w problematykę, która prezentowana jest w kontekście nowości w równym stopniu zaskakującej zarówno medycynę i psychologię, jak i socjologię z polityką społeczną. Pojawiają się również odniesienia pedagogiczne i urbanistyczno-architektoniczne, a wszystko skupione wokół tezy o „dwóch starościach" i ich konsekwencjach.

Zmienia się styl życia i potrzeby seniorów. W tej jednej grupie mieszczą się dziś właściwie dwa pokolenia. Ta młodsza starość - „złota jesień życia” - się emancypuje, ma swoje uniwersytety trzeciego wieku, kluby, organizacje, nordic walking, ta starsza - coraz częściej dożywa setki, przez lata wymagając opieki (Manthey 2017).

Z kolei autorka rozpoczynająca swój artykuł od informacji o „milionie samotnych seniorów" podąża tropem tej drugiej starości, wkraczając w obszar, który lokuje się już bardzo blisko przecięcia z niepełnosprawnością. Tekst został zamieszczony w tygodniku „Polityka” w dziale „Społeczeństwo”, a jego autorka, Edyta Gietka, z wykształcenia polonistka, łączy w swych artykułach styl publicystyczny z artystycznym, wzmacniając środkami językowymi krytyczny aspekt swoich tekstów. „Samotni właściciele lodówek” są figurami starości „,bez bliskich, bez pieniędzy, bez sensu", co prowadzi do poruszenia tematyki zakresu i form opieki oferowanej samotnym seniorom zarówno $\mathrm{w}$ wymiarze usług zapewnianych przez państwo, jak i oferty wolnorynkowej. Życie ludzkie zaprezentowane zostało $\mathrm{w}$ tym przypadku z perspektywy zdehumanizowanych relacji opiekunczych, dla których oczekiwaną alternatywą mogą się stać „zhumanizowane" relacje z urządzeniami:

Świat szykuje się po swojemu na bezpańską starość. Zachód oferuje już starości czujniki ruchu: można niedołężnego zaczipować, zdalnie śledzić wzór jego codziennej aktywności i interweniować $\mathrm{w}$ razie odstępstwa od normy. Japończycy czekają na pierwsze roboty zdolne do zhumanizowanych interakcji. My mamy koperty w lodówce, coś jak blaszany nieśmiertelnik na szyi żołnierza (Gietka 2017b). 
„Niedołężna" starość wpisana w neoliberalną rzeczywistość z jej trans- i posthumanistycznymi aspektami to przecięcie dość oczywiste i jeszcze niezbyt dyskursywnie krytyczne. Ta sama autorka artykułowi poświęconemu starości osób z zespołem Downa nadała tytuł "Starszaki”, któremu towarzyszy całkiem obiektywna informacja wprowadzająca, że "zestarzało się pierwsze pokolenie osób z zespołem Downa, przeżywając ojców i matki" (Gietka 2017c). W dalszej części przedstawiona jest jednak sytuacja ludzi, którzy przez całe życie, traktowani byli jak starsze dzieci, „,starszaki”, które

starość zawdzięczają medycynie. A jeszcze bardziej ojcom i matkom, którzy powypuszczali swoich skośnych z przegrzanych domów, gdzie umierali z nudów przy szklance herbaty. Dziś bodźcuje się ich wedle dostępnej oferty naprawczej, począwszy od integracyjnych przedszkoli.

A ceną jest strach. By nie umrzeć nie w porę. Pierwsze pokolenie ojców i matek uczy się projektowania nie swojej starości (Gietka 2017c).

Starość jest w tym konkretnym przypadku nowością, będącą oczywistym osiągnięciem współczesności i wymiarem postępu przypisywanego nie tylko medycynie, ale i edukacji specjalnej. Specyfika tekstu publicystycznego pozwala na skróty i uogólnienia, ale warto na „dostępną ofertę naprawczą" spojrzeć z perspektywy od dawna obecnej na gruncie interdyscyplinarnych studiów nad niepełnosprawnością. Jednym z obszarów krytycznej analizy są w tym przypadku zarówno segregacyjne korzenie idei szkolnictwa specjalnego, jak i neoliberalna oferta usług terapeutycznych, wzrastająca wraz z zamożnością współczesnych społeczeństw. Można zatem dojść do wniosku, że źle pojęta i niewłaściwie realizowana edukacja specjalna wzmacnia i tak już silną obecność ablizmu, a „w krajach bogatych ekspansja wolnego rynku prowadzi do rozrostu usług edukacyjnych i form wsparcia wzmacniających model intelektualnego i fizycznego dopasowania osób niepełnosprawnych do ekonomicznych warunków pracy" (Roulston, Barnes 2005, za: Goodley 2010: 2). W podobnym duchu w polskim piśmiennictwie pedagogicznym wypowiada się Amadeusz Krause (2010: 182), zestawiając "rehabilitacyjny instrumentalizm" z "paradygmatem humanistycznym", czyli w istocie uzależnienie od wsparcia z podmiotowym udziałem osób z niepełnosprawnością w życiu społecznym, a zwłaszcza debatach poświęconych problemom edukacji specjalnej i rehabilitacji.

Artykuł o starości osób z zespołem Downa to reporterskie miniatury z życia pensjonariuszy domów pomocy społecznej, dożywających swych dni w coraz gorszej kondycji fizycznej i psychicznej, ale przede wszystkim w samotności wspominających, aż do zaniku pamięci, swoje biologiczne rodziny. Traktowani jak dzieci, izolowani od świata, czekają na kolejny krok medycyny, która pozwoli starzejącemu się ciału uniknąć zbyt szybko nadchodzącej demencji. Taka jest wymo- 
wa tekstu kończącego się słowami: „,a medycyna, zmuszona nadążać za własnym geniuszem, już eksperymentuje na hipokampie myszy. Tym razem chodzi o opóźnienie widoku na regres w ZD" (Gietka 2017c).

Starzejące się osoby z niepełnosprawnością to grupa przynajmniej podwójnie wrażliwa (vulnerable), gdyż w zwielokrotniony sposób zagrożona „procesami marginalizacji i wykluczenia społecznego" (Podgórska-Jachnik 2016: 17). Przeciwwagę tych negatywnych zjawisk stanowić może realizacja komplementarnych idei ruchu włączającego w społeczeństwo oraz spójności społecznej, łączących praktyczny dorobek studiów nad niepełnosprawnością i nowoczesne, szerokie strategie polityki społecznej. Przyjmując, że „włączanie (inkluzja) jest (...) przemyślanym procesem zaradczym wobec postrzeganych i niestety nasilających się we współczesnym świecie nierówności społecznych i sił wykluczenia" (tamże, s. 18), w oczywisty sposób przekracza się granice wyznaczone przez pojedynczy czynnik opresji i umożliwia rozwój analiz intersekcjonalnych.

Wprowadzeniem do trzeciego artykułu z „Polityki” autorstwa Edyty Gietki (2017a), poświęconego problematyce eutanazji, powinny być materiały zawarte w dodatku „Niezbędnik Inteligenta”, którego transhumanistyczne pytanie o „sprawność w późnej starości" wykorzystane zostało do zarysowania intersekcjonalnej tematyki niniejszego tekstu. Dobrze tę intertekstualną komunikację ilustruje następujący fragment:

"Nieludzkim jest człowieka uratować i nie dać mu żyćc - mawiał prof. Wiktor Dega, który będąc jednym z najwybitniejszych polskich ortopedów, znał się jednocześnie na rehabilitacji. To przesłanie nie straciło aktualności, a nawet nabrało większego sensu, odkąd można uratować coraz więcej ofiar wypadków i z roku na rok rośnie grupa tych, którym można przywrócić utraconą sprawność. Tymczasem wydaje się olbrzymie pieniądze, by utrzymać ich przy życiu, a później leżą w łóżkach zamknięci w czterech ścianach albo umierają z powodu zapalenia pluc lub odleżyn. Nie jest to medycyna na miarę XXI wieku (Walewski 2017: 63).

Przytoczony fragment pochodzi z tekstu z dodatku do „Polityki”, którego założonym odbiorca jest osoba nie tylko wykształcona, ale i aktywnie korzystająca z dobrodziejstw samodzielnego myślenia („inteligent”). W artykule pod tytułem "Wstań i idź", którego biblijne pochodzenie i retoryczną intencję powinien bez problemu odczytać projektowany, wykształcony odbiorca, zebrane zostały nadzieje i obawy związane z wykorzystaniem $w$ rehabilitacji pourazowej technologii opartych na zaawansowanej elektronice, inżynierii materiałowej i sztucznej inteligencji.

Tygodnik „Polityka” jest obok „Gościa Niedzielnego" najczęściej kupowanym czasopismem opinii w Polsce. Średnia sprzedaż czasopisma, prezentującego obecnie światopogląd lewicowo-liberalny, wyniosła w grudniu 2018 roku 101877 egzemplarzy (https://www.wirtualnemedia.pl/artykul/sprzedaz-tygodnikow-opinii-20- 
18-rok-gosc-niedzielny-sieci, dostęp: 16.03.2019), co dało mu drugie miejsce w tym segmencie rynku prasowego. Ustabilizowana pozycja wśród czytelników pozwala wnioskować, że odbiorcami tekstów zamieszczanych w „Polityce” są osoby regularnie zapoznające się $\mathrm{z}$ treściami prezentowanymi na łamach czasopisma. Jednocześnie można też założyć, że odbiorcy ci dzielą zapewne w dużej mierze ogólny światopogląd kreowany w periodyku, a więc i dyskurs odnoszący się zarówno do ogólnych zagadnień społeczno-politycznych, jak i szczegółowych problemów, których identyfikację odnajdujemy chociażby w analizowanych artykułach Edyty Gietki.

Idąc dalej tym tropem, należałoby się zastanowić, na ile jasny jest dla przeciętnego czytelnika tego czasopisma intersekcjonalny kontekst artykułu na temat eutanazji, w którym wykorzystano wszelkie możliwe w publicystyce środki (językowe), by zarazem przekonywać do postawionej tezy i motywować do (auto)refleksji. Wspomniana teza oparta jest na następującym przecięciu:

Dociągnąłeś - dzięki medycynie - do 80 lat? I jesteś gdzieś pośrodku? Jeszcze nie dość chory, by umrzeć, już nie dość młody, by chorować. W algorytmach NFZ - za stary na procedury. Wiekowo nieopłacalny. Dorosłeś z porażeniem mózgowym dziecięcym? I czujesz się jak niedorżnięty kurczak? Medycyna wyszarpała cię od śmierci, ale nie pomoże żyć (Gietka 2017a).

Teza artykułu to prawo człowieka do decydowania o swoim życiu, co wiąże się z pytaniem o relację tego prawa z prawami innymi (boskimi, naturalnymi, karnymi, obywatelskimi). Humanistyczno-racjonalne podejście do kwestii bioetycznych jest $w$ tym przypadku jednoznacznie po stronie jakości życia zestawianej z jego świętością. Przytaczając argumenty zwolenników obu opcji, autorka prowokuje do namysłu nad kwestiami, które poddały człowieka i jego wolność presji zarówno ze strony postępu naukowego, jak i przesłanek religijnych, które nie są przecież w sprzeczności z zaniechaniem terapii nazywanej uporczywą. Ponownie otrzymujemy miniportrety osób, których aktualna sytuacja stanowi uwiarygodnienie potrzeby przynajmniej debaty nad prawem do godnej, choć wywołanej śmierci. Przecięcie "niedołężnej” starości i „uniesprawniających" chorób osób $\mathrm{w}$ różnym wieku (z zarysowanym jedynie problemem eutanazji dzieci), spotyka się w punkcie, którym jest najczęściej ból, wobec którego medycyna pozostaje bezradna. Cierpieniu fizycznemu towarzyszy trudna psychicznie perspektywa stopniowej utraty kontroli nad własnym ciałem i rosnącej zależności od innych ludzi oraz urządzeń wspomagających pracę organizmu. Podsumowaniem analiz życiorysów osób rozważających eutanazję oraz prezentacji dostępnych w niektórych państwach procedur jest następujące sformułowanie:

Biolodzy przypuszczają, że już niedługo zaczną rodzić się podopieczni medycyny, zaprogramowani na jakieś 120 lat. Etycy, że eutanazja - w kontekście sprzątania po medycynie - będzie najgorętszym sporem tego tysiąclecia (Gietka 2017a). 
Ablizm i ageizm w oczywisty sposób wykluczają słabość powiązaną zarówno ze sprawnością, jak i wiekiem człowieka. Samodzielność sprowadzona do samoobsługi pogłębia zdehumanizowany sposób ujmowania sytuacji człowieka tracącego sprawność, co dotyczy także niesamodzielności - niedołężności ludzi starych. Problematyka eutanazyjna na gruncie studiów nad niepełnosprawnością jest jednoznacznie umiejscawiana $w$ ramach analiz nie tyle bioetycznych, ile biopolitycznych, czerpiąc z poststrukturalnego modelu teoretycznego. Wiąże się to z neoliberalnym wykluczeniem, które postęp technologiczny ogranicza do ludzkiego organizmu i ekskluzywnych towarów i usług, pomijając człowieka jako osobę i podmiot relacji społecznych. By zilustrować biopolityczne uwikłanie ciała, Dan Goodley (2014: 94) przytacza następującą wypowiedź Davida Harveya (1996: 130), antropologa analizującego konsekwencje globalizacji i neoliberalizmu:

Ciało (podobnie jak osoba i jaźń) jest wewnętrzną relacją i dlatego jest dla świata otwarte i porowate... ciało nie jest monadyczne, ani nie unosi się swobodnie w jakimś eterze kultury, dyskursów i przedstawień. Ważne jest jednak to, że może to nastąpić w przypadku materializacji ciała. Studia nad ciałem muszą być osadzone w zrozumieniu rzeczywistych stosunków czasoprzestrzennych między praktykami materialnymi, przedstawieniami, wyobrażeniami, instytucjami, relacjami społecznymi i dominującymi strukturami polityczno-ekonomicznymi.

Niepełnosprawnośći starość, ale także specyficzna sytuacja społeczno-ekonomiczna osób w okresie wczesnej dorosłości, stanowią oczywiste wyzwania współczesności, uwikłanej w ponowoczesną niekonsekwencję aksjologiczną i chaotyczne poszukiwanie idealnych rozwiązań problemów społeczno-ekonomicznych. Nawet tak ograniczona, jak w niniejszym artykule, analiza dyskursu prasowego niepełnosprawności i starości, wskazuje na rozdźwięk między naukowym projektowaniem teraźniejszości i przyszłości człowieka, a rzeczywistą jakością życia osób, których sprawność nie pozwala na samodzielne pokonywanie codziennych trudności życiowych.

\section{Podsumowanie}

Długie lata $w$ zdrowiu (i sprawności) to nie tylko treść okolicznościowych życzeń, ale także przedmiot badań łączących głównie wysiłki biologów i inżynierów. Próba krytycznej analizy fragmentu prasowego dyskursu niepełnosprawności i starości nie pozostawia jednak wątpliwości, że postęp technologiczny nie jest gwarantem ludzkiego szczęścia i autonomii, gdyż kontekstualny wymiar ludzkiego funkcjonowania zakłada harmonijną relację czynników biologicznych i społecznych. Wszelkie zaburzenia pożądanego stanu uruchamiają szereg działań, których wspólnym mianownikiem okazuje się dyskryminacja. Sytuacja osób z nie- 
pełnosprawnością i/lub $\mathrm{w}$ podeszłym wieku jest $\mathrm{w}$ dużym stopniu tożsama, a starość niepełnosprawna, „niedołężna” czy niesamodzielna stanowi oczywisty przykład intersekcji czynników dyskryminacji.

Analiza dyskursu niepełnosprawności i starości ujawnia liczne przecięcia, które można $\mathrm{w}$ dużym uproszczeniu sprowadzić do czynników i praktyk kształtujących zarówno codzienną egzystencję coraz liczniejszej grupy osób, jak i pozornie neutralne projekty społeczne. Niektóre spośród wymienionych na zakończenie zagadnień zostały szerzej zaprezentowane w niniejszym artykule, pozostałe wymagają dalszych studiów i analiz. Do pierwszej grupy można zaliczyć: kult młodości i sprawności; dys/ablizm i ageizm; inkluzja i wykluczenie; sprofilowane usługi, terapia, rehabilitacja; wsparcie społeczne; organizacja czasu wolnego; autonomia i podmiotowość; samotność. Na osobną analizę zasługują natomiast następujące problemy obecne w medialnym dyskursie niepełnosprawności i starości: uniwersalne projektowanie; udział w życiu społecznym i politycznym; praca zawodowa; przemoc fizyczna, psychiczna i ekonomiczna; oszustwa, nadużycia, wykorzystywanie, manipulacje; obecność w mediach i wizerunek medialny.

\section{Bibliografia}

Barnes C., Mercer G. (2008), Niepetnosprawność, tłum. P. Morawski, Wydawnictwo Sic!, Warszawa.

Cieślikowska D. (2010), Dyskryminacja [w:] M. Branka, D. Cieślikowska (red.), Edukacja antydyskryminacyjna. Podręcznik trenerski, Stowarzyszenie Willa Decjusza, Kraków.

Collins P.H. (2015), Intersectionality's De?nitional Dilemmas, Annual Review of Sociology, vol. 41, 1-20.

Crenshaw K. (1989), Demarginalizing the Intersection of Race and Sex: A Black Feminist Critique of Antidiscrimination Doctrine, Feminist Theory and Antiracist Politics, The University of Chicago Legal Forum, vol. 140, 139-167.

Curran T., Runswick-Cole K. (ed.) (2013), Disabled Children's Childhood Studies. Critical Approaches in a Global Context, Palgrave Macmillan, Basingstoke.

Dobek-Ostrowska B., Wiszniowski R. (2001), Teoria komunikowania publicznego i politycznego. Wprowadzenie, Wydawnictwo Astrum, Wrocław.

Duszak A., Fairclough N. (2008), Krytyczna analiza dyskursu - nowy obszar badawczy dla lingwistyki i nauk społecznych [w:] A. Duszak, N. Fairclough (red.), Krytyczna analiza dyskursu. Interdyscyplinarne podejście do komunikacji społecznej, Wydawnictwo Universitas, Kraków.

Giddens A. (2007), Socjologia, tłum. A. Szulżycka, Wydawnictwo Naukowe PWN, Warszawa.

Gietka E. (2017a), Eutanazja.info, „Polityka”, 1-10-2013, http://www.polityka.pl/tygodnik polityka/spoleczenstwo/1556763,1,eutanazja--gdy-zyc-sie-juz-nie-chce.read [dostęp: 2.11.2017].

Gietka E. (2017b), Samotni właściciele lodówek, „Polityka”, 03-02-2015, http://www.polityka. pl/tygodnikpolityka/spoleczenstwo/1607311,1,starosc-bez-bliskich-bez-pieniedzy-bezsensu.read [dostęp: 1.11.2017]. 
Gietka E. (2017c), Starszaki, „Polityka” 11-11-2014, http://www.polityka.pl/tygodnikpolityka/ spoleczenstwo/1598905,1,ludzie-z-zespolem-downa-zyja-coraz-dluzej.read [dostęp: 2.11.2017].

Goodley D. (2010), Disability Studies: An Interdisciplinary Introduction, Sage Publications Ltd., London.

Goodley D. (2011), Disability Studies: An Interdisciplinary Introduction, Sage Publications Ltd., London.

Goodley D. (2014), Disability Studies, Routledge, London.

Goodley D., Hughes B., Davis L. (ed.) (2012), Disability and Social Theory. New Developments and Directions, Palgrave Macmillan, London.

Grzymała-Kazłowska A. (2004), Socjologicznie zorientowana analiza dyskursu na tle wspótczesnych badan nad dyskursem, Kultura i Społeczeństwo, t. XLVIII, 13-34.

Harvey D. (1996), The body as an accumulation strategy [w:] D. Harvey, Spaces of Hope, University of California Press, Berkeley-Los Angeles.

Hyży E. (2010), Kobieta, ciało, tożsamość. Teorie podmiotu w filozofii feministycznej końca XX wieku, Universitas, Kraków.

Johnson R. (2009), Gender, rasa, klasa i seksualna orientacja. Teoretyczne ujęcia intersekcjonalności, tłum. E. Charkiewicz, Biblioteka Online Think Tanku Feministycznego, http://www. ekologiasztuka.pl/pdf/f0068johnson.pdf [dostęp: 21.10.2017].

Krause A. (2010), Wspótczesne paradygmaty pedagogiki specjalnej, Oficyna Wydawnicza „Impuls", Kraków.

Leszczyńska-Rejchert A., Kantowicz E. (red.) (2012), Stereotypy a starość i niepetnosprawność, Wydawnictwo Akapit, Torun.

Manthey E., Starość to nowość, „Gazeta Wyborcza”, 07-08-2017, http://wyborcza.pl/7,75400, 22201260,starosc-to-nowosc.html [dostęp: 1.11.2017].

Międzynarodowa Klasyfikacja Funkcjonowania, Niepełnosprawności i Zdrowia (2001), WHO, Genewa [w:] Centrum Systemów Informacyjnych Ochrony Zdrowia, 2013, http://www.pfon.org/dokumenty-i-publikacje/klasyfikacja-icf/496-miedzynarodowa-klasyfikacja-funkcjonowania-niepelnosprawnosci-i-zdrowia-icf-polskie-tlumaczenie [dostęp: 21.10.2017].

Podgórska-Jachnik D. (2016), Studia nad niepetnosprawnością (Disability Studies) i ruch właczajacy w spoteczeństwo jako konteksty edukacji włączającej, Problemy Edukacji, Rehabilitacji i Socjalizacji Osób Niepełnosprawnych, t. 22(1), 16-33.

Roulstone A., Barnes C. (eds.) (2005), Working Futures: Disabled People, Policy and Social Inclusion, Bristol: The Policy Press.

Topinková E. (2008), Aging, Disability and Frailty, Annals of Nutrition and Metabolism, vol. 52 (suppl. 1), 6-11.

Walewski P. (2017), Wstań i idź, Polityka. Niezbędnik Inteligenta, nr 2, 60-63.

Wendell S. (1996), The rejected body: feminist philosophical reflections on disability, Routledge, New York. 